\title{
Application of the TROPOS Method to Development a Website-Based Blood Stock Management System at Palang Merah Indonesia (PMI) in Bandung City
}

\author{
Rinda Firma Violita ${ }^{[1]^{*}}$, Sri Widowati ${ }^{[2]}$, Prati Hutari Gani ${ }^{[3]}$ \\ Bachelor of Informatics Engineering, Faculty of Informatics \\ Telkom University, Bandung, Indonesia \\ ${ }^{[1]}$ rindaviolita@students.telkomuniversity.ac.id, ${ }^{[2]}$ sriwidowati@telkomuniversity.ac.id, \\ ${ }^{[3]}$ pratihutarigani@telkomuniversity.ac.id
}

\begin{abstract}
Palang Merah Indonesia (PMI) is a social organization in the city of Bandung. In the business process, the blood donor section has not used any software that satisfies the need to connect communities and PMI on blood donor information. So it takes software that can help the process of running blood donor business to minimize the problems that occur such as human error and not spread information about blood supply. RE (Requirement Engineering) is an early stage as an important task, as many software failures come from inconsistent, incomplete or just wrong specification requirements. In $\mathrm{RE}$ there is a process that is requirement analysis to do analysis of user needs. Goal Oriented Requirements Engineering (GORE) is one of the models that can be used to analyse user needs. One method on the GORE model is the TROPOS method. The use of TROPOS on the development of the blood stock management software to focus on the needs analysis on the stages of modeling early requirement and late requirement. The results of the analysis are implemented into web software design. Software that has been created based on the modeling evaluated using BlackBox Testing with user acceptance test (UAT) by stakeholders. Based on the results of the assessment UAT score, the results of the respondents assessment is $3.55 \%$, so that the blood stock management software can be used as a supporting tool to run the blood stock business process of PMI.
\end{abstract}

Keywords-requirements, goal oriented requirement engineering, TROPOS, Blackbox testing.

\section{INTRODUCTION}

Software development at the Indonesian Red Cross (PMI) can help facilitate the assignment process and the data recording process, so that the process has been computerized. Software created to bridge information between PMI and Blood Donor Family. the results of elicitation requirements by interview the problems faced by blood donor family in obtaining information online are still very limited, the information needed is in the form of the availability of a blood donor mobile unit schedule, the amount of blood stock available and blood donor registration. With the software so that it can solve the problems that exist in PMI.

The main measure of the success of a software is the extent to which the software fulfills its purpose. Therefore, identifying goals must be one of the main activities in developing software systems[1]. One of the activities in software development is defining requirements which are conditions that must be met or owned by a system to meet a standard or specification of what must be implemented[2]. Management and documentation of a software must pass an agreement on changes to a software[3]. In the statement of objectives there is one functionality needed, namely, Requirements Engineering (RE) is the process of defining the needs of a software from stakeholders and the system environment to be built [4]. One approach to requirements engineering is to use goal-oriented needs engineering methods (Goal-Oriented Requirements Engineering / GORE) [5]. The presence of GORE complements the inadequacy of traditional RE that focuses on the system. However, GORE is complemented by giving a reason for system functionality by answering "why" such functionality is needed [6]. GORE brings benefits to RE practices with appropriate criteria for completing adequate requirements specifications [7].

There are several methods in GORE, one of which is Tropos[8]. This approach was chosen because it has a more complete requirements mechanism than the other approaches, besides that this approach has the design of an automatic goal model mapping of the system architecture. This approach adopts modeling languages and model analysis techniques, which are developed into an agent-oriented software development methodology. Tropos model on the requirements mechanism as a whole includes the software development life cycle which consists of 5 phases, namely early requirements, late requirements, architectural design, detailed design and implementation, but the needs identification phase is divided into two stages, namely early requirements and late requirements. The existence of these two stages in the Tropos method can help simplify the model and provide an opportunity to detail the needs in the next phase [9]. So to solve the problem at PMI using the TROPOS method which will be implemented into software in the blood supply business process. 


\section{LITERATURE REVIEW}

\section{A. Requirement Engineering ( $R E)$}

Requirement Engineering (RE) is the process by which the requirements of the system are determined. RE involves activities to find the needs of stakeholders, understand the context of requirements, modeling, validation, documentation and managing existing requirements [10]. To find out which software is free from various problems, it must be known what problems must be solved. However, to find what needs to be discussed, the problem must be resolved and anyone who has to be involved in the problem needs to be found and analyzed.

Technical requirements on the use of systematic and repetitive techniques that complement the completeness, consistency and relevance of a system requirement. [Sommerville 1997a]. The requested process is:

1. Requirements

2. Need analysis

3. Requirement specifications

4. Verification of requirements

5. Management needs

In the process of technical requirements there are three types, namely top down, middle out and bottom up. In this final project, the topdown type is selected, which is a process that starts from the target and task in the destination system, collects information that is related and material, classification and described in full can be accepted by the user.

Elicitation requirements on requirements engineering are the practice of gathering requirements from users, customers, and other stakeholders. The purpose of this process is to understand the problems that exist in the problem domain. The understanding is then used to perform formal specifications on requirements [11]. Like the following approved software requirements [12]:

1) Unambiguous

There is only one interpretation of the requirements document.

2) Tested

A system can be implemented, it is certain that the system meets the initial requirements.

3) True

The specifications are written correctly and in accordance with user requirements.

4) Delete

The specifications must be exact for the classification feature to be built.

5) Understandable

All agreed terms can be understood as specified in the document.

6) Feasible

As needed, according to available technology, within budget, and according to time and schedule.

7) Required

Required requirements are requirements that must exist to meet the objectives of the system, it is very important for system requirements, and if the needs are not necessary it will cause deficiencies in the system.

\section{B. Goal Oriented Requirement Engineering(GORE)}

Goal Oriented Requirement Engineering (GORE) is an approach in RE that is oriented towards goal identification. Goals are changed into a requirement (requirements). Most traditional approaches, more emphasis on modeling requirements in the form of low-level data, operations, and others that are more understood by other internal programmers \& developers, while stakeholders / users / customers tend to be less concerned with such modeling. While the Goal model (GORE) is also equipped on the high-level side [13]. GORE defines goals as the goals to be achieved by a system of cooperation between agents in a customer's software-to-be and environment [14]. The requirements-oriented requirements give rise to help in identifying requirements in the form of high-level objectives which must be included in the temporary software according to stakeholder needs. The objective requirements oriented engineering (GORE) approach is concerned with activities that lead to the main requirements of the software. It mainly consists of the following activities: goal bringing, refinement of objectives and various types of goal analysis, and task responsibilities for goals for agents, GORE approaches namely NFR framework, $\mathrm{i} *$ / TROPOS, KAOS, GBRAM[15].

\section{TROPOS}

This approach adopts modeling language and model analysis technique $\mathrm{i} *$, which is developed into an agentoriented software development methodology. Compared to other similar models, the TROPOS model has a broader scope in a system development phase, especially in the requirements phase [16]. The TROPOS methodology is intended to support all analysis and design activities in the software development process, from the application domain analysis to system implementation. In particular, TROPOS relies on the idea of building a model of a prospective system and its environment, which is gradually being refined and expanded, providing a common interface for various software development activities, as well as a basis for documentation and software evolution[17]. Based on the results of studies from previous researchers [18], when comparing with similar models, the Tropos model has a broader scope in a system development phase, the phase is divided into 5 phases, namely early requirements, late requirements, architectural design, detailed design and implementation. The STOPOS Methodology stages are illustrated in Fig.1.

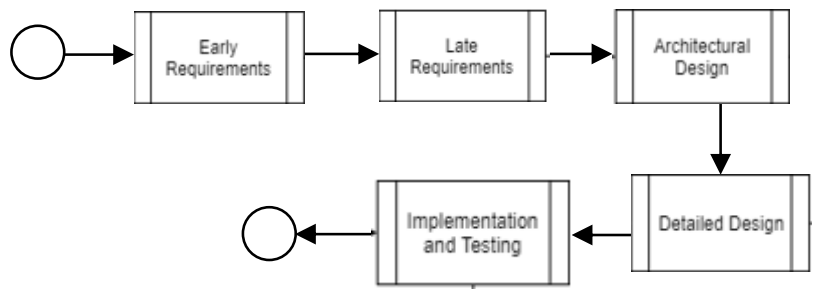

Fig.1. Stages TROPOS [18]

Modeling the system using Tropos is based on a conceptual metamodel with elements including [19]: 


\section{1) Goal}

Consists of hardgoal and softgoal, goal states the actor's strategic interest. Hardgoal is an objective based on the actor / organization that must be achieved. Softgoal in software development can be likened to non-functional needs.

2) Actor

Actors can be physical, social, or software agents or roles or roles. In the Tropos model, roles are defined as characteristics of the behavior of social actors, and position states.

3) Plan

Stating how something in the objectives to be achieved. Carrying out a plan means trying to fulfill a goal.

4) Dependency

It is two actors stating that one actor to achieve a goal, implement a plan, need / produce resources, depends on other actors. Actors who depend on actors are dependers, while actors who are dependent depend on them. The objects around the center of interdependence are called dependums.

5) Resource

Is a physical or information entity.

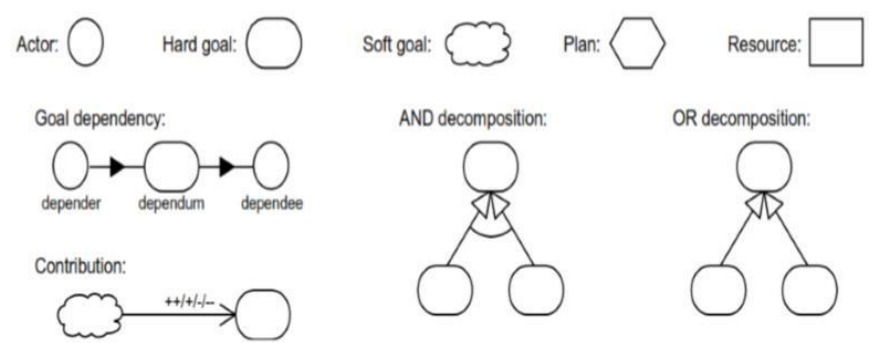

Fig.2. Metamodel Tropos [19].
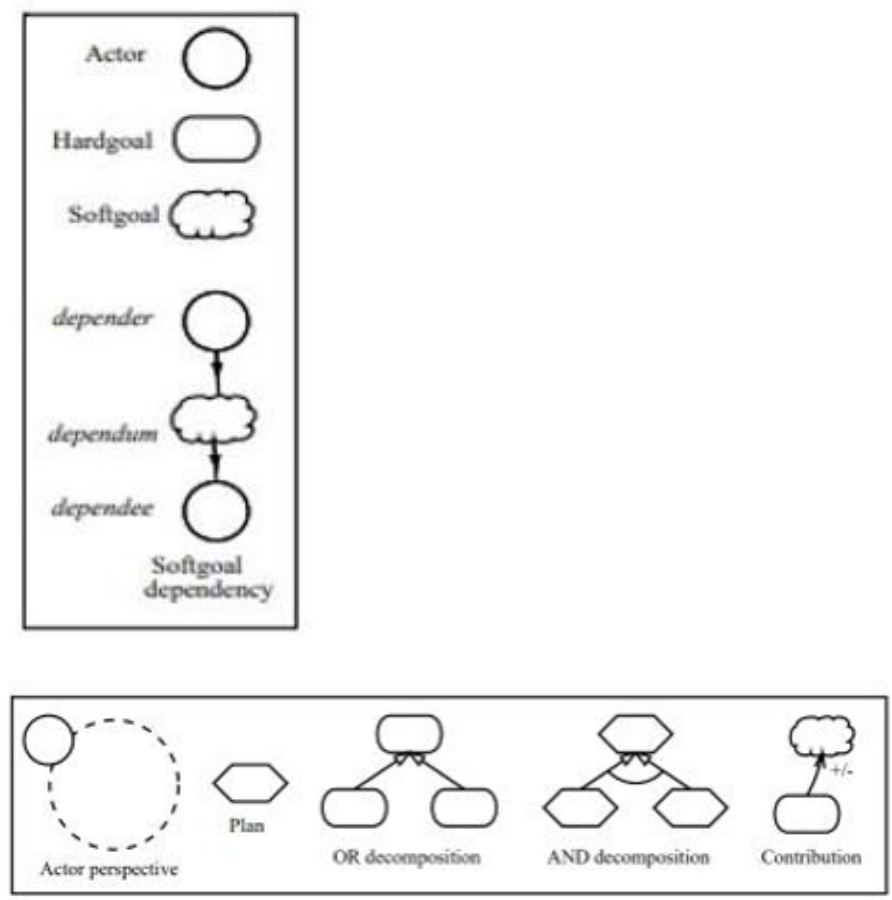

Fig.3. Notation in Modeling TROPOS [17]
In this research, a case study of the Bandung city PMI was taken using the TROPOS method. The TROPOS method has a broader scope in a system development phase, especially in the identification phase of needs, this phase includes two stages, namely early requirements and late requirements. In describing TROPOS modeling there is a notation like in Fig.3.

\section{Blackbox Testing}

Black Box Testing is a test that focuses on the functional requirements of the software. Black Box Testing is also called behavioral testing or partition testing. Black Box Testing allows software engineers to get a series of inputs that fully use all functional requirements for a program. Black Box Testing tries to find:

1. Functions that are incorrect or missing.

2. Interface Error.

3. Errors in data structures or external database access.

4. Performance error.

5. Initialization and termination errors.

To apply the Black Box testing technique, a series of tests is needed [20]. Black box testing focuses on the functional requirements of the software. Thus, black box testing allows software engineers to get a set of input conditions that fully use all functional requirements for a program.

User Acceptance test (UAT) is a testing process involving a set of data that someone makes an Acceptance Decision as a software acceptance decision. Tests carried out by users are intended to produce documents to be used as evidence that software that has been developed can be accepted by users, if the results of testing (testing) can be considered to meet the needs of users [21].

The Boundary value analysis is one of the techniques in the black Box testing method that focuses on the input process by testing the upper limit value and lower limit value. The working principle of BVA is:

1. Many mistakes occur when the input process;

2. BVA works on the input process.

Black box testing algorithm with boundary value analysis technique is as follows:

1. If the input condition is in the range of $\mathrm{x}$ and $\mathrm{Y}$ values, then the test case must be created with sample data of $\mathrm{X}$ $1, \mathrm{x}, \mathrm{y}, \mathrm{y}+1$.

2. If the input condition uses a number of values, the test case must be created for a minimum sample data of -1 , minimum, maximum, maximum of +1 .

3. Perform steps 1 and 2 for the output process.

4. If the data already has input constraints (e.g., set max. $10)$, then the test case is created at that limit [22].

E. Palang Merah Indonesia(PMI) Bandung City

PMI is a humanitarian organization that is a legal entity, enacted by Law number 1 of 2018 concerning 
Kepalangmerahan in order to carry out the activities of the Kepalangmerahan in accordance with the Geneva Conventions of 1949 , with the aim of preventing and alleviating suffering and protecting victims of war prisoners and disasters, without distinguishing religion, nation, ethnicity, color, sex, class, and political views. At present, PMI has been established in 33 Provinces, 474 Regencies / Cities and 3,406 Districts (data as of February 2019). PMI has almost 1.5 million volunteers ready to provide services

\section{RESEARCH METHOD}

\section{A. Research Flow}

Research Flow The research is conducted based on the research model in Fig.4. The picture explains the research flow that will be carried out, starting from the Elicitation stage.

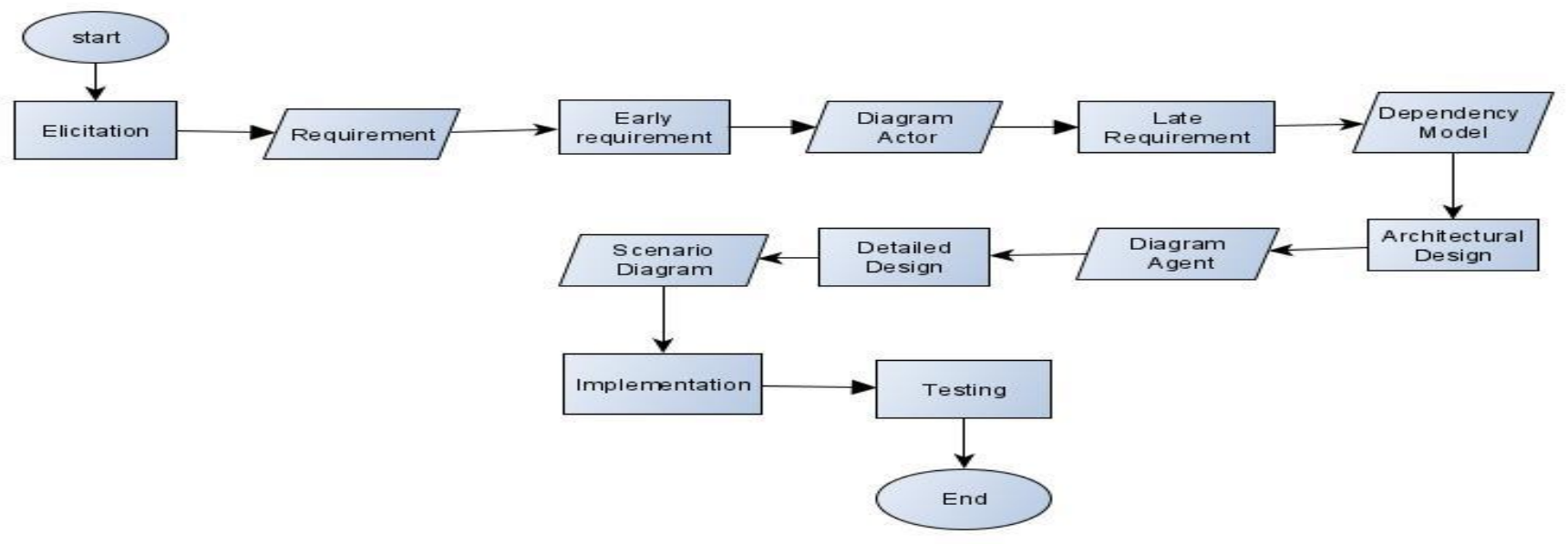

Fig.4. Research Flow

\section{B. Elicitation}

At this stage, requirement gathering activities are carried out, wherein this activity is carried out in direct interaction with relevant parties in the Information Technology (IT) section of PMI. The elicitation process is the first stage in requirements engineering, which is the process of identifying software requirements from various sources, which are used in this study, namely interviews and document analysis with sources to find out the identification of business needs, goals and problems in managing blood stocks. The information from these things aims to find out the initial goal (initial goal) in the domain. Questions asked to the IT field are in TABLE 1.

TABLE 1 Question Elisitation[17]

\begin{tabular}{|l|l|l|}
\hline NO & \multicolumn{1}{|c|}{ Pertanyaan } & \multicolumn{1}{|c|}{ Stakeholder } \\
\hline 1 & Who are the stakeholders ? & Leader unit IT \\
\hline 2 & $\begin{array}{l}\text { How does the business flow in } \\
\text { the assignment process? }\end{array}$ & $\begin{array}{l}\text { Leader unit IT,Unit blood } \\
\text { unit strorage }\end{array}$ \\
\hline 3 & $\begin{array}{l}\text { What problems are there? } \\
\text { Leader unit IT, Unit blood } \\
\text { unit storage }\end{array}$ \\
\hline 5 & $\begin{array}{l}\text { What business goals are } \\
\text { expected? }\end{array}$ & Leader unit IT \\
\hline 6 & $\begin{array}{l}\text { What kind of software is } \\
\text { want? }\end{array}$ & Leader unit IT \\
\hline
\end{tabular}

\section{TROPOS}

\section{Early Requirement}

The initial stage to develop the model using the TROPOS method is the early requirements stage. This modeling is done by drawing a diagram consisting of actors, goals, and resources needed to achieve these goals and relationships between various components. The modeling explains the current domain conditions (as-is) related to problems in business processes. A guide for starting to build an early requirement model is given an analysis question as in TABLE 2

TABLE 2 early requirement

\begin{tabular}{|l|l|l|}
\hline NO & \multicolumn{1}{|c|}{ Pertanyaan } & \multicolumn{1}{|c|}{ Stakeholder } \\
\hline 1 & $\begin{array}{l}\text { Who are the stakeholders } \\
\text { (stakeholders in the domain } \\
\text { management blood stock? }\end{array}$ & Leader unit IT \\
\hline 2 & What are the goals for each actor? & $\begin{array}{l}\text { Leader unit IT, Unit blood } \\
\text { unit storage }\end{array}$ \\
\hline 3 & $\begin{array}{l}\text { What resources are needed for each } \\
\text { goal? }\end{array}$ & $\begin{array}{l}\text { Leader unit IT, Unit blood } \\
\text { unit storage }\end{array}$ \\
\hline 4 & $\begin{array}{l}\text { How is the relationship between } \\
\text { actors forachieving goals? }\end{array}$ & Leader unit IT \\
\hline
\end{tabular}

The results of the questions with the scope of stakeholders, goals, resources and linkages between actors, the Early Requirement analysis in the actor diagram. 


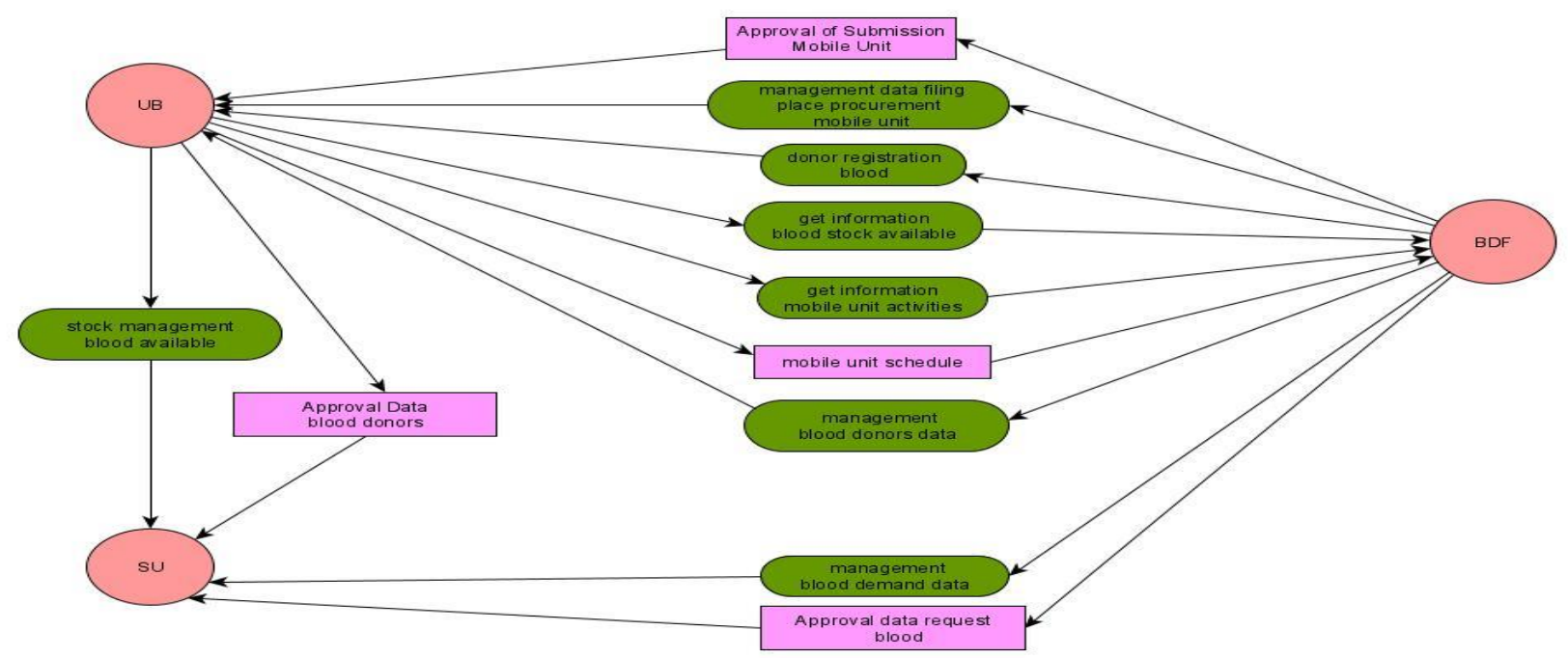

Fig.5. Early Requirement Diagram Aktor

\section{Late Requirement}

The next stage in the development of the TROPOS method model is the late requirement stage, a more detailed identification of goals based on early requirements identification will be carried out by decomposing the main goals into several sub-goals according to the function of each actor. At this stage it focuses on system-to-be in the operating environment. This stage begins by introducing a new actor domain model and having a number of dependencies with other actors in the organization. This dependency defines the functional and non-functional requirements of the system. TABLE 3 presents guidelines for conducting analytical questions for modeling late requirements.
TABLE 3 Analisis Late Requirement

\begin{tabular}{|l|l|l|}
\hline NO & \multicolumn{1}{|c|}{ Pertanyaan } & \multicolumn{1}{c|}{ Stakeholder } \\
\hline 1 & $\begin{array}{l}\text { What are the goals that can be set } \\
\text { for the system-to-be candidate? }\end{array}$ & Leader unit IT \\
\hline 2 & $\begin{array}{l}\text { Which dependencies are there } \\
\text { can be transferred from the actor } \\
\text { domain to software? }\end{array}$ & $\begin{array}{l}\text { Leader unit IT,Unit blood, } \\
\text { Unit storage }\end{array}$ \\
\hline
\end{tabular}

The results of the questions with the scope of the goal for the prospective system and the actor dependency analysis of the Late Requirements in the picture dependency model.

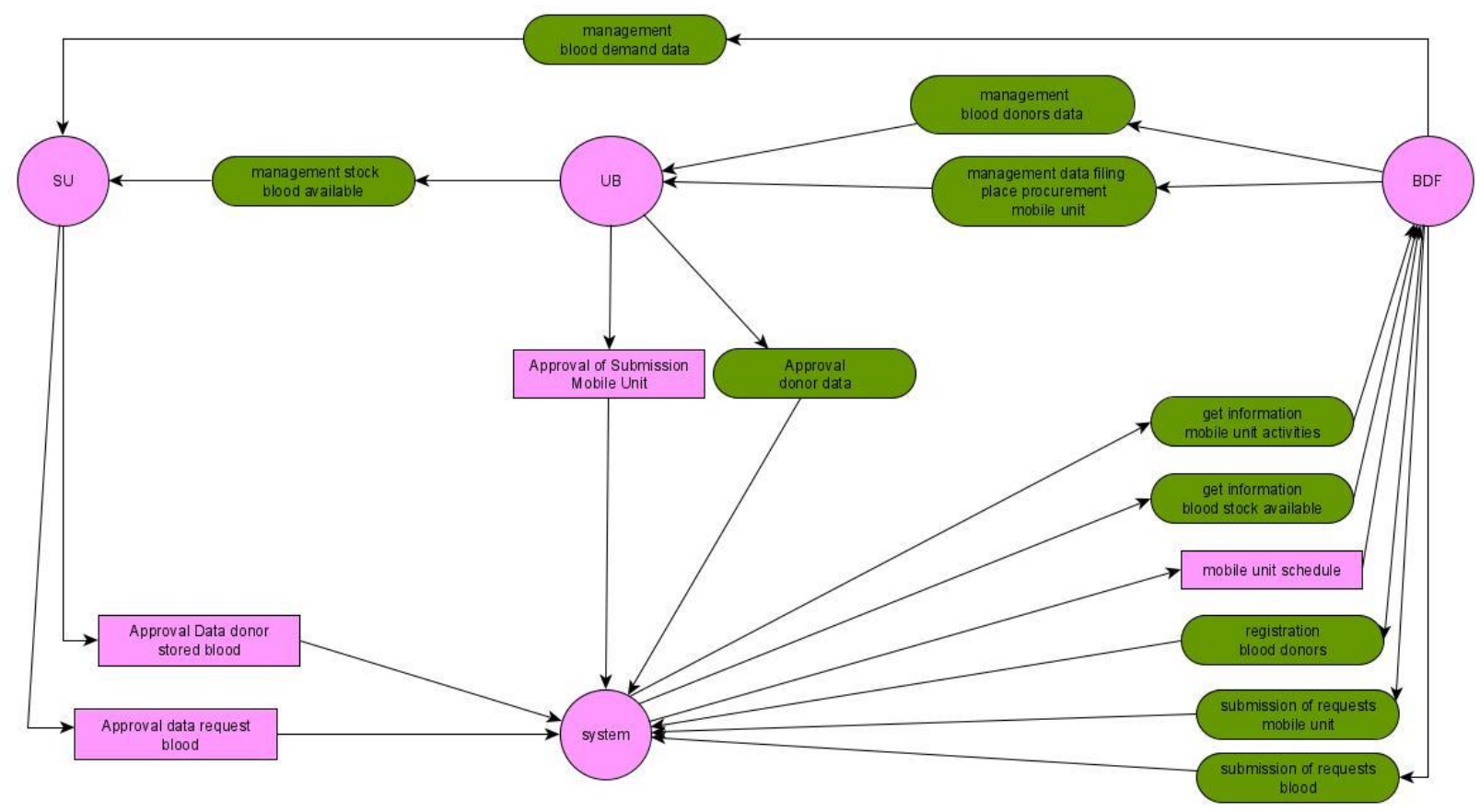

Fig.6. Dependency Model 


\section{Architectural Design}

The stages of design in the Tropos method are Architectural Design and Detail Architectural design consists of the overall structure of the system, the design is represented in the form of sub-systems and their interdependencies based on modeling of late requirements [17]. To build architectural design, the initial stage is by introducing sub-actors, who are responsible for carrying out the main objectives of the system. The aim is to break the complexity of the system, which is explained in terms of high-level goals into smaller components, easier to design, implement and manage.

This stage relates to the specification of the ability of software agents in the system and the interactions that occur, with a focus on the input-output aspect, which leads to a detailed definition of how each agent behaves to carry out the plan to fulfill its objectives [17]. In the Tropos method the next step to model the detailed steps is to take the input specifications generated from the architecture design phase, besides that at this stage using UML activity diagrams to represent capabilities and plans.

Architectural design describes a set of types of agents and assigns each of them one or more different abilities (assignment of agents). In general, agent assignments are not unique and depend on the designer. The number of agents and abilities assigned to each of them is a choice driven by the analysis of the extended actor diagram and by the way in which the designer thinks the system is in agent terms.

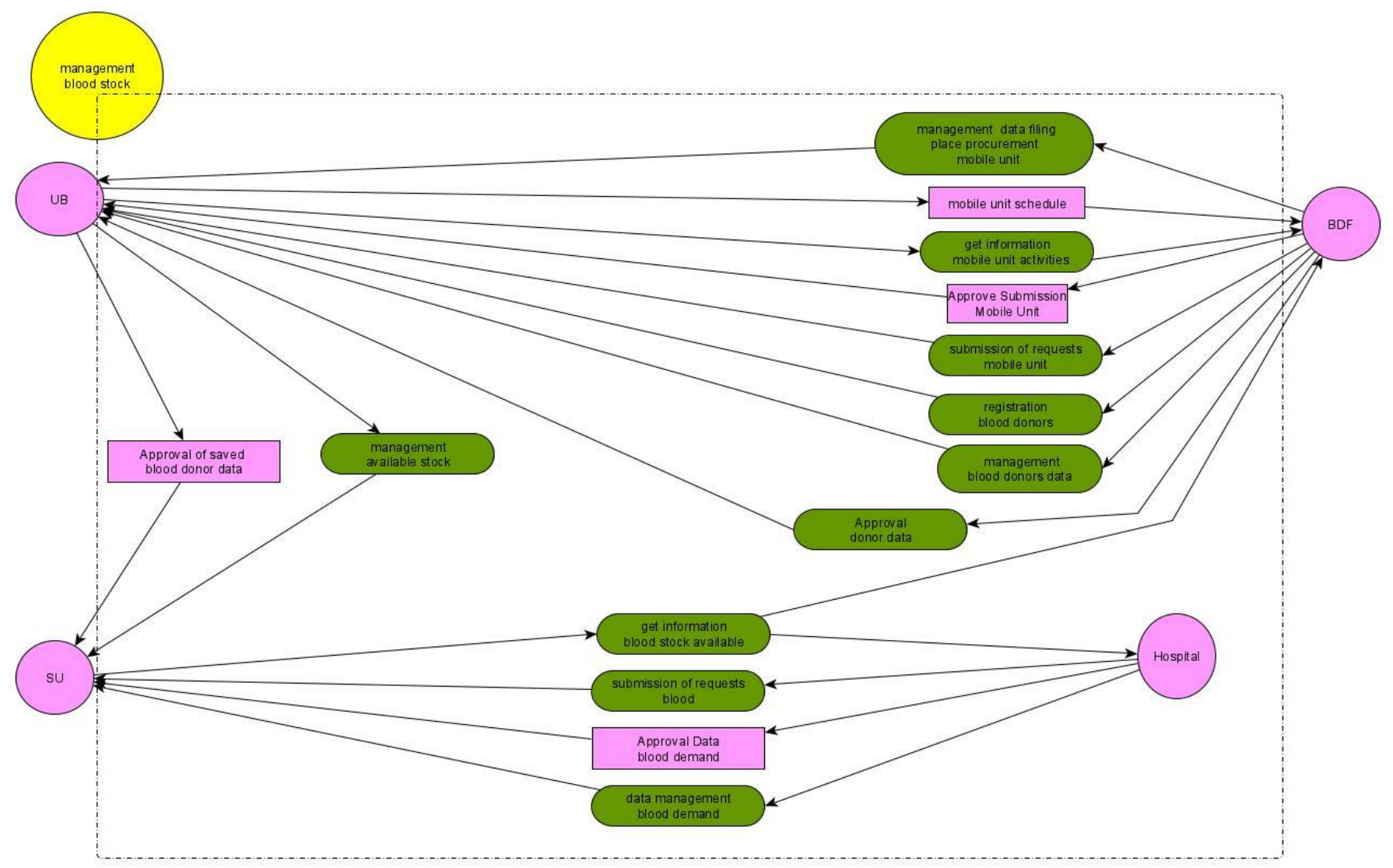

Fig.7. Diagram Agent

TABLE 4 Architectural Design

\begin{tabular}{|l|l|l|l|}
\hline NO & Actor & Capabilities & Sub Actor \\
\hline 1 & $\begin{array}{l}\text { Unit } \\
\text { blood }\end{array}$ & $\begin{array}{l}\text { Data management } \\
\text { blood donors } \\
\text { mobile unit }\end{array}$ & \\
\cline { 3 - 4 } & & $\begin{array}{l}\text { Management of place } \\
\text { submission data }\end{array}$ & \\
\cline { 3 - 4 } & & $\begin{array}{l}\text { Approve Submission } \\
\text { Mobile Unit }\end{array}$ & \\
\cline { 3 - 4 } & Approve donor data & \\
\hline
\end{tabular}

\begin{tabular}{|l|l|l|l|}
\hline 2 & $\begin{array}{l}\text { Blood } \\
\text { donor } \\
\text { family }\end{array}$ & $\begin{array}{l}\text { Get information } \\
\text { mobile unit activities }\end{array}$ & \\
\cline { 4 - 4 } & $\begin{array}{l}\text { Registration } \\
\text { blood donors }\end{array}$ & \\
\cline { 3 - 4 } & $\begin{array}{l}\text { Submitting a request } \\
\text { mobile unit }\end{array}$ & \\
\cline { 3 - 4 } & mobile unit schedule & \\
\cline { 3 - 4 } & $\begin{array}{l}\text { submission of requests } \\
\text { blood }\end{array}$ & Hospital \\
\cline { 3 - 4 } & $\begin{array}{l}\text { Get stock information } \\
\text { blood available }\end{array}$ & Hospital \\
\hline
\end{tabular}




\begin{tabular}{|l|l|l|l|}
\hline 3 & \multirow{2}{*}{$\begin{array}{l}\text { Storage } \\
\text { unit }\end{array}$} & $\begin{array}{l}\text { data management } \\
\text { blood demand }\end{array}$ & \\
\cline { 3 - 4 } & & $\begin{array}{l}\text { Management stock } \\
\text { blood available }\end{array}$ & \\
\cline { 3 - 4 } & & $\begin{array}{l}\text { Approval Data } \\
\text { blood pedonor stored }\end{array}$ & \\
\cline { 3 - 4 } & $\begin{array}{l}\text { Approval Data } \\
\text { blood demand }\end{array}$ & \\
\cline { 3 - 4 } & &
\end{tabular}

From the modeling image above it can be explained that in the blood stock management information system created there are 3 actors integrated with each other. Each actor described has the capabilities (capabilities) each. In this study each subactor has a goal analysis that is interdependent to the actor, capability and sub-actor.

\section{Detail Design}

Design details related to the agent micro level specifications. At the detailed modeling stage the design capabilities, protocols, and tasks / plans of the agent are specified in detail, UML activity diagrams are used to represent capabilities. UML activity diagrams make it possible to model capabilities (or a series of correlated capabilities) from the point of view of a particular agent

This stage is carried out based on the architectural design stages, the system design can be completed by detailing more detailed plans related to each goal of each actor with sub-actors and capabilities. At this stage, it is done using UML diagrams, namely activity diagrams, which can make it possible to model each capability based on the perspective of each actor to the sub-actors.

\section{a) Management of data blood demand}

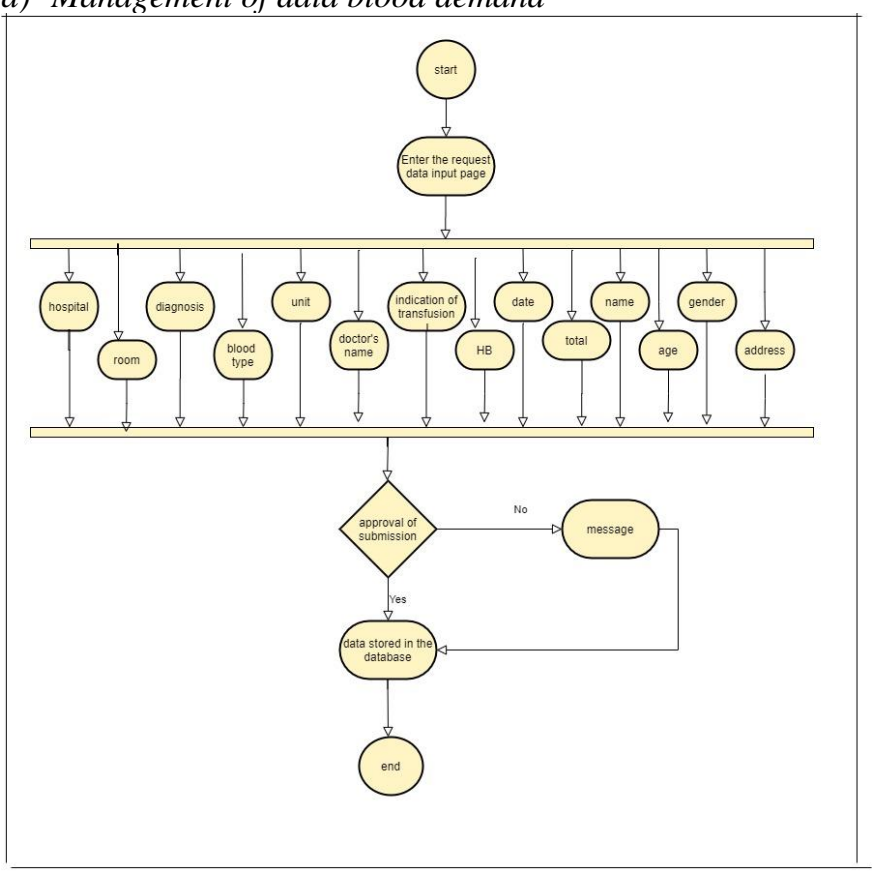

Fig.8. Management of data blood demand b) Management of data blood donor

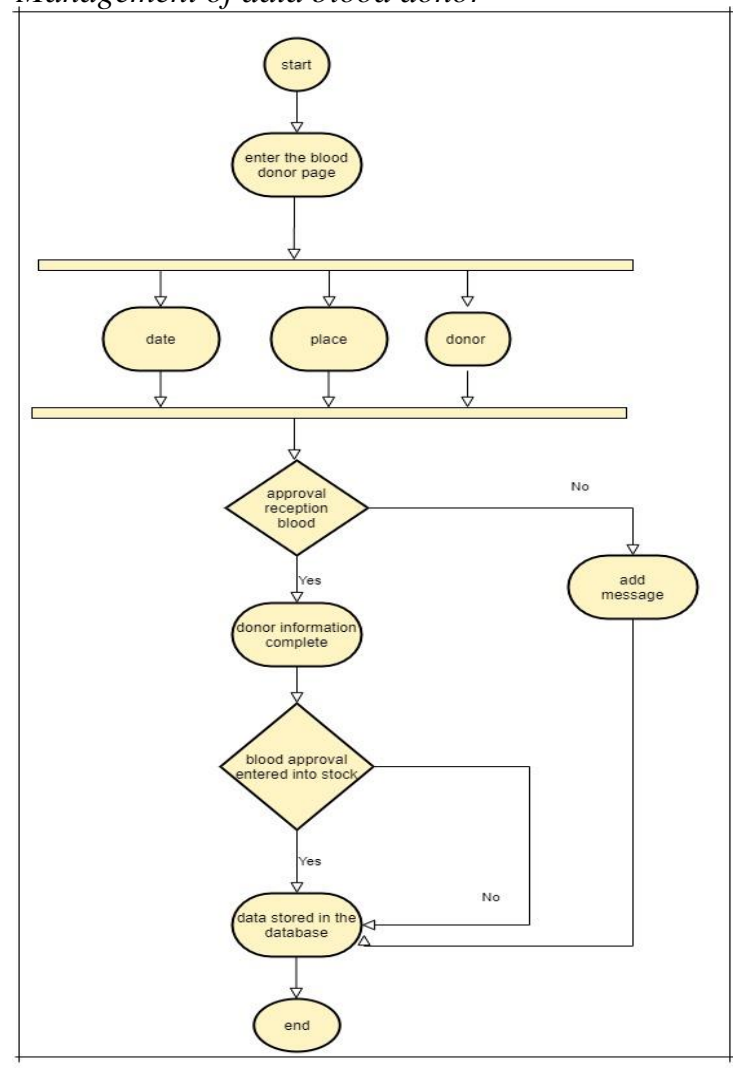

Fig.9. Management of data blood donor

c) Management of place submission mobile unit

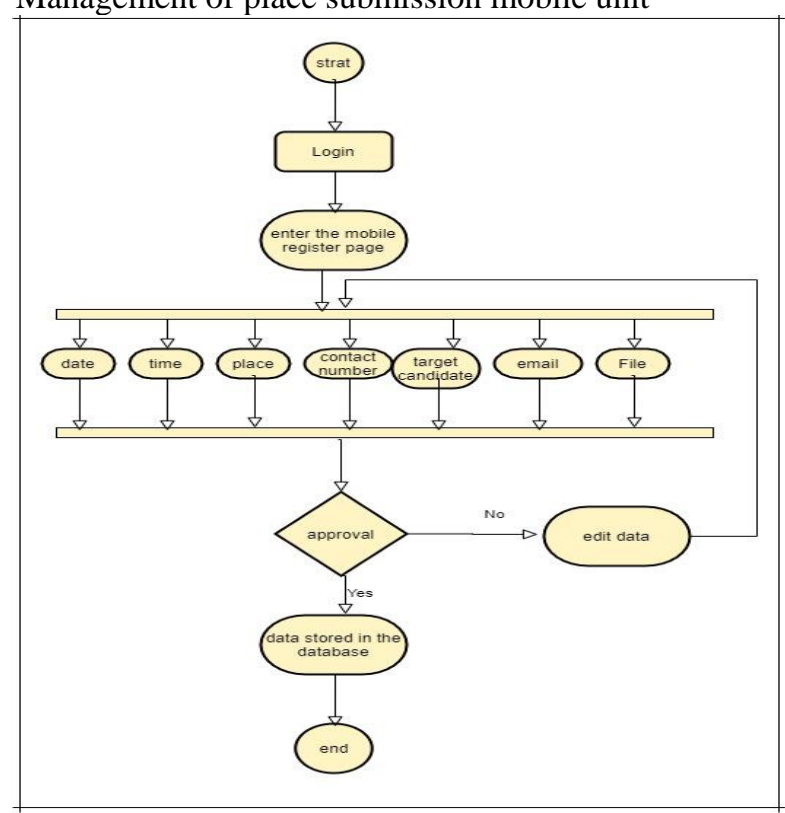

Fig.10. Management of place submission mobile unit

IV. ANALYSIS AND RESULT

A. Implementation

In this stage, website development is carried out using the Hypertext Prepocessor (PHP) programming language with 
Code Igniter (CI) and MySql frameworks as database storage. The website development process is based on user requirements specifications that have been analyzed and designed in the form of modeling as mentioned earlier.

Display of the built application blood stock management

1) Display Home of stock blood

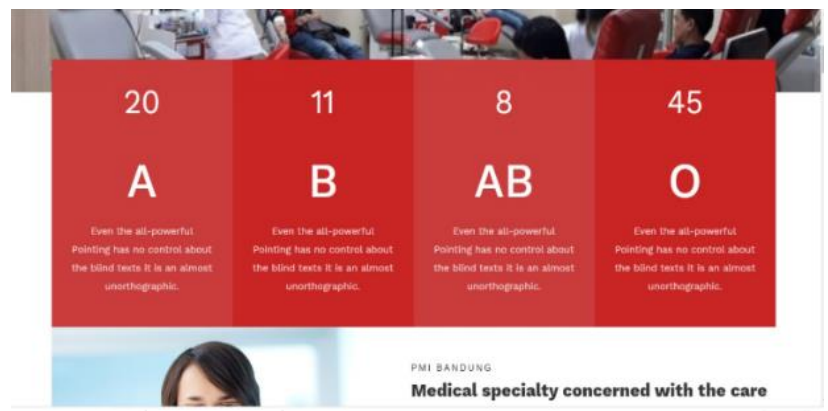

Fig.11. Display home of stock blood

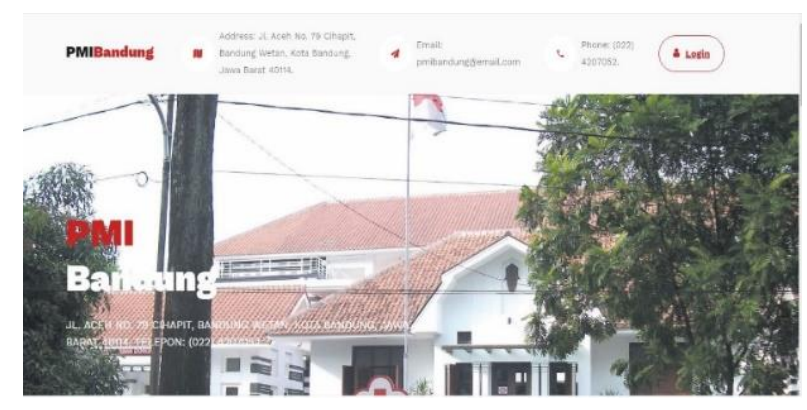

Fig.12. Display home of stock blood

\section{2) Display of blood donor data}

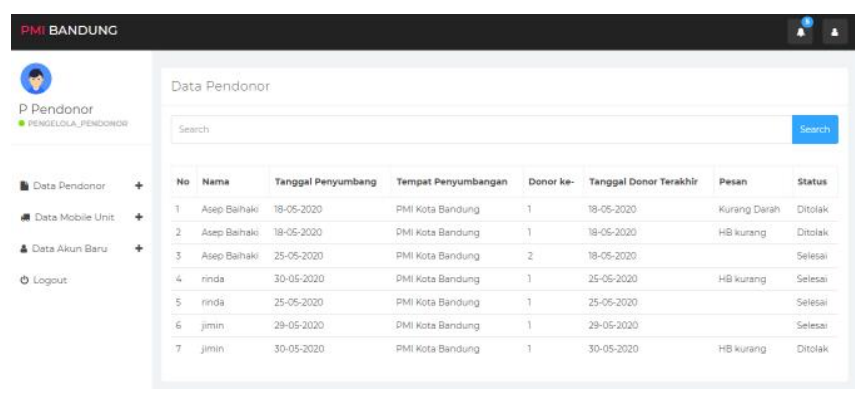

Fig.13. Display of blood donor data

3) Display of mobile unit data

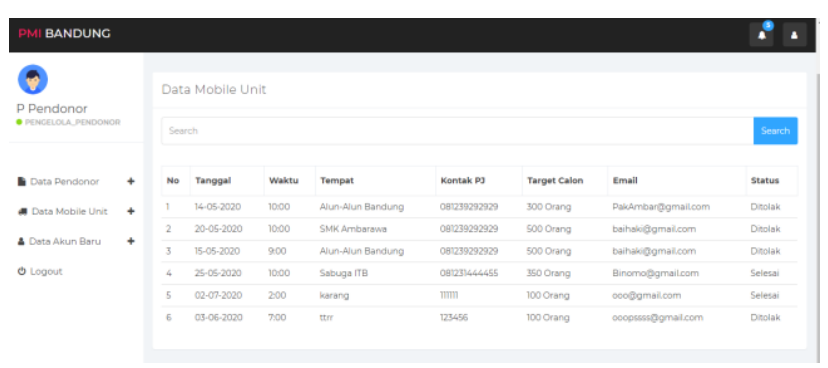

Fig.14. Display of mobile unit data

\section{4) Database stock blood}

TABLE 5 Database blood stock

\begin{tabular}{|c|c|}
\hline Tb_profile & \\
\hline *No_registration: bigint(20) & Tb_mobile_unit \\
\hline NIK: bigint $(233)$ & *Id_mobile_unit: int(233) \\
\hline Name: varchar(255) & Date : varchar(20) \\
\hline place_born: varchar(255) & Time: varchar(20) \\
\hline Date_born: varchar(40) & Place: varchar(233) \\
\hline Gender: varchar(40) & Contact_number: \\
\hline Type_blood: varchar(255) & $\frac{\text { varchar( } 233)}{\text { Taroet candidate } \cdot \text { varchar }}$ \\
\hline Address_home: varchar(255) & 1223) \\
\hline Rt: $\operatorname{varchar}(20)$ & Email : varchar(223) \\
\hline Rw: varchar(20) & Status: $\operatorname{int}(40)$ \\
\hline village: varchar(100) & Message: varchar(223) \\
\hline sub-district: varchar(233) & Document: varchar(223) \\
\hline $\begin{array}{c}\text { City: varchar(100) } \\
\text { Postal_code: } \operatorname{varchar}(40)\end{array}$ & \#No_registration: \\
\hline Profession: varchar(100) & \\
\hline
\end{tabular}

Tb_pendonor

Address office: varchar(100)

Contact_office: varchar(100)

Email: varchar(100)

Username: varchar(100)

Password: varchar(100)

Contact_number: varchar(100)

User_type: $\operatorname{varchar}(40)$

Status_account: int(40)

\begin{tabular}{|c|}
\hline Tb_stock \\
\hline *Id_stock: int(11) \\
\hline $\begin{array}{c}\text { Type_blood: } \\
\text { varchar(10) }\end{array}$ \\
\hline Total: int(255) \\
\hline \#Id_pendonor: int(233) \\
\hline Status: varchar(12) \\
\hline
\end{tabular}

*Id_pendonor : int(233)

Date_donation: varchar(223)

Place_donation: varchar(223)

Reward: varchar(223)

Donor: varchar(223)

Date_donot_last: varchar(223)

Status : varchar(223)

Message: varchar(223)

\#No_registration: bigint(20)

\begin{tabular}{|c|}
\hline Tb_Request \\
\hline Id_Request: int(233) \\
\hline Unit: varchar(233) \\
\hline Room: varchar(233) \\
\hline Doctor: varchar(233) \\
\hline Diagnosis: varchar(233) \\
\hline Indication_tranfusion: \\
varchar(233) \\
\hline Hb: varchar(233) \\
\hline Name: varchar(233) \\
\hline Age: varchar(233) \\
\hline Gender: varchar(233) \\
\hline Address: varchar(233) \\
\hline Message: varchar(233) \\
\hline Status: varchar(25) \\
\hline No_registration: $\operatorname{int}(20)$ \\
\hline Type_blood: $\operatorname{varchar}(40)$ \\
\hline Total: varchar(40) \\
\hline Date: varchar(40) \\
\hline Time: varchar(40) \\
\hline Id_hospital: $\operatorname{int}(40)$ \\
\hline
\end{tabular}

Tb_hospita

Id hospital: int(40)

Name_hospital:varchar(255)

Address_hospital: varchar(255)

Contact hospital: varchar(255) Username: varchar(255)

Password: varchar(233)

User_type: varchar(233)

Status_account: varchar(40) 


\section{B. Testing}

Testing can be done to show that each function operates fully, at the same time looking for errors in each function. If the software is considered, then Black Box testing with user acceptance tests relates to tests conducted on the software interface[23].

TABLE 6 Form User Acceptance Test of storage unit [23]

\section{Change Check List:}

\begin{tabular}{|c|c|c|}
\hline 1 & Login & $\nwarrow \checkmark$ OK \\
\hline 2 & management of blood demand data & $\sqrt{ }$ \\
\hline 3 & management of blood stock available & $\sqrt{ }$ \\
\hline 4 & Change password & $\sqrt{ }$ \\
\hline
\end{tabular}

TABLE 7 Form User Acceptance Test of blood unit

\section{Change Check List:}

\begin{tabular}{|c|c|c|}
\hline 1 & Login & $\nwarrow$ OK \\
\hline 2 & Managing data submission for mobile units & $\sqrt{ }$ OK \\
\hline 3 & Approval donor data & $\nwarrow$ OK \\
\hline 4 & Change password & $\nwarrow$ OK \\
\hline
\end{tabular}

TABLE 8 Form User Acceptance Test of hospital

\section{Change Check List:}

\begin{tabular}{|c|c|c|}
\hline 1 & Login & 『 OK \\
\hline 2 & submission of blood requests & 『 OK \\
\hline 3 & Get information blood stock available & 『 OK \\
\hline 4 & Change password & 『 OK \\
\hline
\end{tabular}

TABLE 9 Form User Acceptance Test of blood donor family

\section{Change Check List:}

\begin{tabular}{|c|c|c|}
\hline 1 & Login & $\sqrt{ }$ OK \\
\hline 2 & Blood donor registrar & $\sqrt{ }$ OK \\
\hline 3 & Submission of mobile unit & $\sqrt{ }$ OK \\
\hline 4 & $\begin{array}{c}\text { Get information on mobile unit activities and } \\
\text { blood stock available }\end{array}$ & $\sqrt{ }$ OK \\
\hline 5 & Change password & $\sqrt{ }$ \\
\hline
\end{tabular}

TABLE 10 Test Result

\begin{tabular}{|c|c|c|c|}
\hline NO & Hak Akses & Rating succes & (rating x 100\%) \\
\hline 1 & Blood donor family & $4 / 5$ & 0,8 \\
\hline 2 & storage unit & $4 / 4$ & 1 \\
\hline 3 & Blood Unit & $3 / 4$ & 0,75 \\
\hline 4 & Bank blood & $4 / 4$ & 1 \\
\hline & & & Total $: 4,55 \%$ \\
\hline
\end{tabular}

Based on the results of the analysis of needs analysis using the Tropos method modeling, it can be seen from 4 respondents agreeing to needs that are made based on business processes and processes by showing the results of testing as much as 3,55\% based on the calculation of blackbox testing by users of the Acceptance Test. These results indicate that the application of the Tropos method to the assignment information system in blood stock management in the PMI city of Bandung can be applied, because it shows the results of satisfaction in the needs made with Tropos modeling of 3,55\%, while for the results the result is $0,45 \%$ still has lack of features to be built is still lacking in detail.

\section{CONCLUSIONS}

Tropos method has advantages in the requirements phase, especially in the needs identification phase. The advantage of this phase is because of the early requirement phase that can identify the current domain conditions (as-is) related to understanding the problems of business processes and the late requirements phase analyzing the objectives of the prospective system (system-to-be). This research was conducted to evaluate the modeling using the Tropos method, the results of the modeling were built by blood stock management software to intersect between PMI and the community. software that was built passed validation using Blackbox testing. Based on the results of the validation of needs analysis using the Tropos method modeling, that of the 4 respondents showed an accuracy of $3,55 \%$ based on blackbox testing calculations with user acceptance tests. In this study modeling using the Tropos method in the blood stock management system at the Bandung city of PMI, that the method can be applied to the case studies taken. While the remaining $0,45 \%$ results are a drawback of the requirements needed for the features built.
REFERENCES

[5] Stasiun Jawa Barat."
F. A. Maulana, S. Widowati, and J. H. Husen, "Penerapan Metode Tropos pada Sistem Informasi Penugasan di Bidang Program TVRI

Y. Kamalia, "Implementasi Goal Oriented Requirement Engineering Menggunakan Knowledge Acquisition in autOmated Spesification Untuk Pengelolaan Administrasi Kepolisian Sindangkerta," 2019.

D. A. Murhayanti, N. Selviandro, and D. Junaedi, "Visualisasi Requirement Engineering Berbasis Pendekatan Graph Menggunakan Metode Requirement Engineering Visualization Based on Graph Approach Using Force-Directed Method."

G. Huzooree, "International Journal of Advanced Research in Computer Science and Software Engineering A Systematic Study on Requirement Engineering Processes and Practices in Mauritius," Comput. Sci. Softw. Eng., vol. 5, no. 2, pp. 40-46, 2015.

J. Horkoff et al., "Goal-oriented requirements engineering: an extended systematic mapping study," Requir. Eng., vol. 24, no. 2, 
pp. 133-160, 2019, doi: 10.1007/s00766-017-0280-z.

[6] S. Aljahdali, J. Bano, and N. Hundewale, "Goal Oriented Requirements Engineering -A Review Goal Oriented Requirements Engineering - A Review," no. January 2011, pp. 328-333, 2015.

[7] P. P. Negri, V. E. S. Souza, A. L. D. C. Leal, R. D. A. Falbo, and G. Guizzardi, "Towards an ontology of goal-oriented requirements," CIbSE 2017 - XX Ibero-American Conf. Softw. Eng., pp. 165-178, 2017.

[8] I. M. Shofi and E. K. Budiardjo, "Klasifikasi Metode Goal Oriented Requirement Engineering ( Gore ) Dan Kemungkinannya Untuk Mengembangkan Aplikasi Kepemerintahan,” Semin. Nas. Teknol. Inf. dan Komun. Terap., 2011.

[9] A. H. Wibawa, E. Darwiyanto, F. Informatika, and U. Telkom, "Perencanaan Strategis Sistem Informasi Pada SMA Negeri 1 Rembang Menggunakan Metode Anita Cassidy Method," vol. 4, no. 3, pp. 4824-4831, 2017.

[10] M. F. A. Z, S. Widowati, and R. R. Riskiana, "Implementasi Scenario Based Requirement Engineering Menggunakan Scenariobased Requirement Analysis Method Untuk Karyawan Bagian Program Dan Anggaran KPU Pusat."

[11] A. B. Satiti, M. K. Sabariah, and N. Selviandro, "Implementasi dan Evaluasi Tipe dan Teknik Visualisasi Requirements pada Aktivitas Elisitasi Requirements," pp. 1-6.

[12] S. Group, "IBM Rational RequisitePro evaluators guide ."

[13] A. Lapouchnian, "Goal-Oriented Requirements Engineering: An Overview of the Current Research Goal-Oriented Requirements Engineering: An Overview of the Current Research by Alexei Lapouchnian Department of Computer Science," no. December, 2013.

[14] A. Khair, "IMPLEMENTASI DAN ANALISIS GOAL-BASED REQUIREMENT ANALYSIS METHOD ( GBRAM ) DENGAN STUDI KASUS: SISTEM INFORMASI APOTEK ANANDA IMPLEMENTATION AND ANALYSIS GOAL-BASED REQUIREMENT ANALYSIS METHOD ( GBRAM ) ON CASE STUDY : ANANDA PHARMACY INFORMATION SYSTEM."

[15] M. Fatima, "KAOS : A Goal Oriented Requirement Engineering Approach," Int. J. Innov. Res. Sci. Technol., vol. 1, no. 10, pp. 133$135,2015$.

[16] F. A. Syahman, S. Widowati, and R. R. Riskiana, "Penerapan Metode TROPOS Untuk Rekayasa Kebutuhan Pada Pembangunan Sistem Informasi Pengelola Gudang Mobil di PT . Istana Bandung Raya Motor," vol. 6, no. 2, pp. 9313-9324, 2019.

[17] P. Bresciani, P. Giorgini, A. Perini, and F. Giunchiglia, "Corruption and unethical behavior: report on a set of Danish guidelines," J. Bus. Ethics, vol. 51, no. 1, pp. 31-39, 2004, doi: 10.1023/B.

[18] M. Cossentino, V. Hilaire, A. Molesini, and V. Seidita, Handbook on agent-oriented design processes, no. January. 2014.

[19] I. S. Suwardi, K. Surendro, and U. Widyatama, "Pemodelan Kebutuhan Sistem Informasi Menggunakan TROPOS,” pp. 8-9, 2018

[20] Z. Khairunnisa, F. Susanti, and R. Hendriyanto, "Aplikasi Pengelolaan Cuti Pegawai Berbasis Web Studi Kasus: Kantor Sekretariat Kota Administrasi Jakarta Utara Web-Based Application of Employee Leave Management Case Study: Secretariat Office of North Jakarta Administration," Appl. Sci., vol. 5, no. 2, pp. 1093 1103, 2019.

[21] F. Andila, P. Aji, and W. Wikusna, "Aplikasi Monitoring Aktivitas Intrakurikuler dan Ekstrakurikuler Siswa Berbasis Web ( Studi Kasus: SMP Pasundan 6 Bandung ) Web-Based Student Intracurricular and Extracurricular Activity Monitoring Application ( Case Study: SMP Pasundan 6 Bandung )," 2013.

[22] T. S. Jaya, "Pengujian Aplikasi dengan Metode Blackbox Testing Boundary Value Analysis (Studi Kasus: Kantor Digital Politeknik Negeri Lampung)," J. Inform. Pengemb. IT, vol. 3, no. 2, pp. 45-46, 2018, doi: 10.30591/jpit.v3i1.647.

[23] E. W. Yunarso, Student Workbook Jaminan Mutu Sistem Informasi. Yogyakarta: DeePublished, 2013. 